\title{
Paleomagnetism of Unzen volcano: A volcanic record (Senbongi excursion) of the Iceland Basin event and the Brunhes VGP distribution for Japan
}

\author{
Hidetoshi Shibuya $^{1}$, Yuki Iwasaki ${ }^{1,4}$, Hidefumi Tanaka ${ }^{2}$, and Hideo Hoshizumi ${ }^{3}$ \\ ${ }^{1}$ Kumamoto University, Dept. of Earth Sciences, Kumamoto 860-8555, Japan \\ ${ }^{2}$ Kochi University, Dept. of Education, Kochi 780-8520, Japan \\ ${ }^{3}$ Geological Survey of Japan, AIST, 1-1-1 Higashi Tsukuba 305-8567, Japan \\ ${ }^{4}$ Central Soft Co., Ltd, Sundisk-Kanda Bdg., Kandaiwamoto-cho, Chiyoda-ku, Tokyo 101-0033, Japan
}

(Received January 4, 2007; Revised March 23, 2007; Accepted May 18, 2007; Online published July 20, 2007)

\begin{abstract}
A paleomagnetic study was carried out on volcanic rocks from Unzen volcano: samples were collected from a total of 69 sites with 19 sites in pyroclastic flows and 50 sites in lava flows. Ages for the flows were determined either by K-Ar methods or detailed field surveys, and indicate that all of the flows were deposited during the Brunhes chron. After demagnetization 10 pyroclastic and 48 lava flows had stable site-mean directions. One lava flow in the Senbongi area with a K-Ar age of $197 \pm 17 \mathrm{ka}$ had an intermediate virtual geomagnetic pole (VGP) at $8.3^{\circ} \mathrm{N}, 21.6^{\circ} \mathrm{E}$. The age and VGP position apparently correlate with the Iceland Basin event, suggesting that it is a record of the event on volcanic rocks. Our study added 53 Brunhes-aged VGPs to the overall collection for Japan, increasing it by $40 \%$ to a total of 175 VGPs. After excluding all site-mean directions having $\alpha_{95}>10^{\circ}$ and VGP latitude $<50^{\circ}$, the remaining 148 VGPs have a mean pole at $89.7^{\circ} \mathrm{N}, 40.9^{\circ} \mathrm{E}\left(A_{95}=2.2^{\circ}\right)$ showing no significant deviation from the geographic pole. The angular standard deviation (ASD) was calculated as $15.2^{\circ} \pm 1.2^{\circ}(N=148)$, which is compatible with paleosecular variation models from the literature. However, the data set was found to deviate from a Fisher distribution. The actual meaning of the ASD value after removing the intermediate VGPs needs to be reconsidered.
\end{abstract}

Key words: Geomagnetic excursion, Iceland basin event, PSVL, Unzen volcano.

\section{Introduction}

Unzen volcano, which is situated on the western side of Kyushu Island, Japan, was active during the period from 1991 to 1995 (Nakada et al., 1999; Hoshizumi et al., 1999). The eruptions killed 44 people and the pyroclastic and debris flows destroyed more than 2,000 homes. In order to better understand the hazards associated with the volcano, the Japanese government undertook a number of geologic and geophysical studies. The projects included the Unzen Scientific Drilling Project (USDP) and its auxiliary field studies related to flows in the drill core. A comprehensive paleomagnetic investigation of the Unzen volcano was carried out as a part of the field studies. The objectives of this investigation were two fold: 1) To apply paleomagnetism to volcanological problems, such as assessing the settling temperature of pyroclastic flows and correlating individual lava flows, and 2) to study the record of geomagnetic activities, namely, secular variation and short geomagnetic episodes, within the Brunhes chron. Results related to the first objective have already been reported (Tanaka et al., 2004), and this paper concerns the recorded behavior of the geomagnetic field.

Lava flows have long been studied to unravel the record of paleosecular variation (PSVL) of the geomagnetic field.

Copyright (c) The Society of Geomagnetism and Earth, Planetary and Space Sciences (SGEPSS); The Seismological Society of Japan; The Volcanological Society of Japan; The Geodetic Society of Japan; The Japanese Society for Planetary Sciences; TERRAPUB
In a PSVL study each paleomagnetic direction for a lava flow is thought to represent a "snap shot" of the local geomagnetic direction at a point in time when the lava flow cooled, and the statistical parameters of the site-mean directions and/or virtual geomagnetic poles (VGPs) are used to characterize the geomagnetic secular variation. It is essential to determine the shape of the distribution, and this requires much more data than needed to determine the statistical parameters assuming a given distribution. Thus, the accumulation of PSVL data is important for improving our understanding of the geomagnetic field.

As subjects of a PSVL study, Unzen volcanic rocks have two distinct advantages: (1) Detailed geological studies of the volcano have already been made, and (2) reliable ages are available for almost all of the geological units on the volcano, made primarily by the Geological Survey of Japan (GSJ) which is a leading institute of the USDP. Although resolution of the dates is well below the typical periods of geomagnetic secular variation, they are very useful in evaluating the paleomagnetic results.

Another important purpose of the paleomagnetic studies of Brunhes volcanic rocks is finding a geomagnetic excursion, which is a major swing of the geomagnetic field from the axial-dipole field direction. Although existence of geomagnetic excursions used to be a subject of controversy (e.g. Roberts and Piper, 1989), they are now commonly accepted due to improvements in magnetic measurements, dating and correlation of excursion reports in marine sediment cores (e.g. Channell, 1999), and several reliable re- 
ports from volcanic rocks (e.g. Shibuya et al., 1992; Tanaka and Kobayashi, 2003). Volcanic records of geomagnetic excursions are important, since they serve as tie points between sediment stratigraphy and radiometric ages, and as calibration points for relative geomagnetic paleointensity logs measured from sediment cores to absolute ones from volcanic rocks. Fortunately, we have found a reliable record of a geomagnetic excursion in a lava flow from Unzen volcano.

\section{Geology and Paleomagnetic Measurements}

Unzen Volcano has been active for approximately half a million years, and during this time has erupted mostly dacitic lava and pyroclastic flows. It is situated in the Beppu-Shimabara graben that cuts Kyushu Island from east to west; the graben has also given rise to a number of other volcanoes. Tectonic subsidence of the normal-faulted graben is about $2 \mathrm{~mm} / \mathrm{yr}$, and volcanic materials have filled in the rift zone. Unzen volcanic rocks are divided into younger and older units based on topography and stratigraphy, and this classification has been verified in most areas by $\mathrm{K}-\mathrm{Ar}$ ages determined for the USDP. The rock units of "Younger" Unzen were found to range between $150 \mathrm{ka}$ and $0 \mathrm{ka}$ while those of "Older" Unzen range between 500 ka and 150 ka (Hoshizumi et al., 2003). Without ages, it is difficult to distinguish petrographically or geochemically between the older and younger Unzen rocks. Pre-Unzen andesitic and basaltic rocks that underlie Unzen Volcano are between 4.3 and 0.5 million years old.

Paleomagnetic samples were collected from 46 sites in lava flows and 19 sites in pyroclastic flows within the Unzen dacite, and from 4 lava flows in the pre-Unzen andesites and basalts that are from 0.8 to $0.5 \mathrm{Ma}$ in age. Figure 1 shows the distribution of site locations, and these and the age data are tabulated in Table 1. Many paleomagnetic sites are in the same outcrops that were sampled for geochronology by the USDP, or are in flows that are well correlated with dated flows. Paleomagnetic samples were collected primarily using a portable gasoline-powered drill and diamondtipped drill bits (core diameter of $25 \mathrm{~mm}$ and length usually $>100 \mathrm{~mm}$ ), and were oriented using a magnetic compass. A sun compass was also used for orientation whenever possible. The magnetic and sun orientations were compared by Tanaka et al. (2004) and were not found to be significantly different for the dacitic rocks of Unzen Volcano. At a few sites in the pyroclastic flows hand samples were collected because the cobble-sized blocks were too difficult to drill. A block orientation tool consisting of a magnetic compass attached to a tripod, commonly used by Japanese paleomagnetists, was used for all hand samples with measurement errors nearly as good as those for the field drilled cores. Usually more than 7 independently oriented samples were taken from each site. Hand samples were drilled with a press in the laboratory to yield cylindrical cores with the same dimensions as those drilled in the field. All cores were then cut into specimens $25 \mathrm{~mm}$ in length.

Laboratory measurements were mostly carried out at $\mathrm{Ku}$ mamoto University. The instruments used in this study were a Natsuhara-Giken SSM-85 spinner magnetometer, a Natsuharra-Giken DEM-8601 tumbling demagnetizer, and

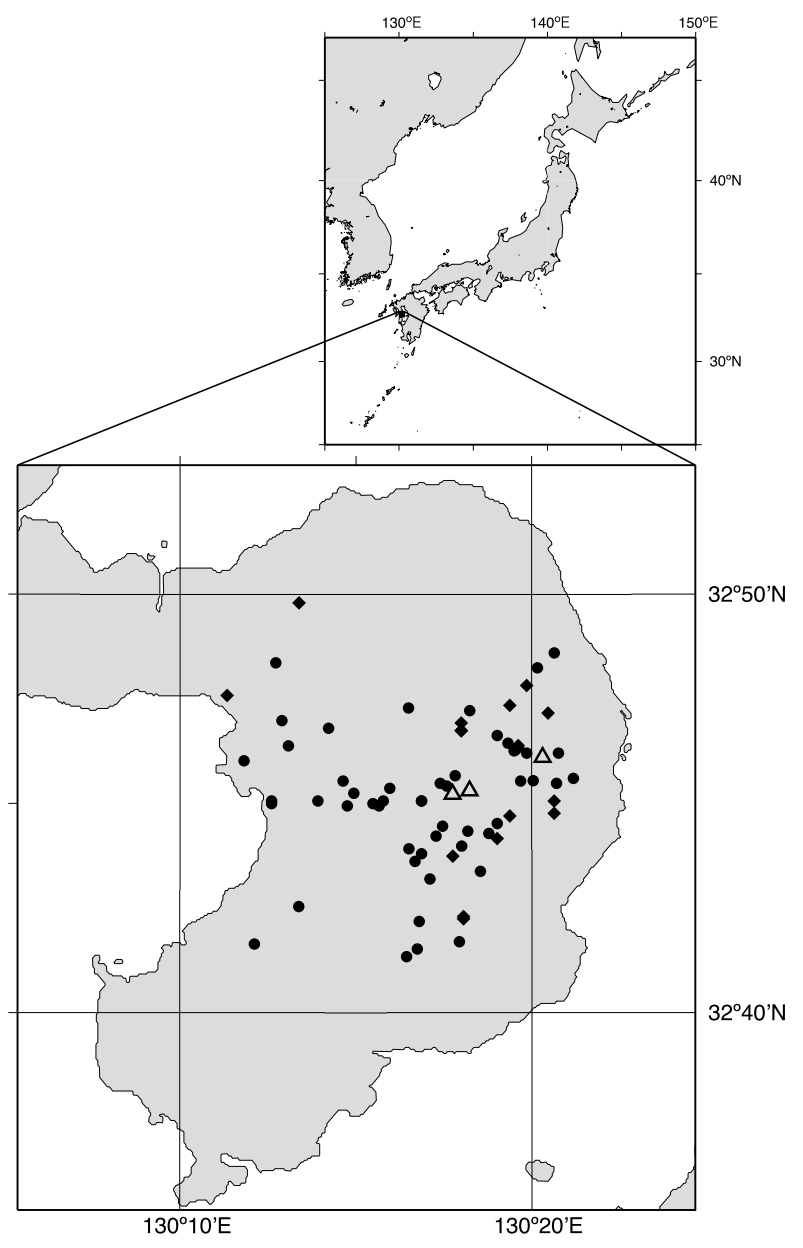

Fig. 1. Map showing the sampling sites. Circles and diamonds represent the lava and pyroclastic sites, respectively. Triangles are Fugendake, Heisei-shinzan and Mayuyama mountains, from left to right.

a Schonstedt TSD-1 thermal demagnetizer that are all situated in a geomagnetic field-free room. Some measurements were also made using similar Natsuhara-Giken instruments at Kochi University. Before any demagnetization procedures were undertaken, the natural remanent magnetization (NRM) of each specimen was measured. For sites in the lava flows an appropriate pilot specimen was then selected and was progressively demagnetized using alternating fields (a.f.) at 14 steps up to $100 \mathrm{mT}$. If the majority of the remanence was not removed, a sister specimen was subjected to thermal demagnetization to $680^{\circ} \mathrm{C}$ or until the NRM was completely removed. If the characteristic component (ChRM) was clearly defined in the orthogonal a.f. demagnetization plot, then specimens from the site's remaining samples were demagnetized at a single 'blanket' step to define the ChRM. Otherwise, the other samples were also progressively a.f. demagnetized. All samples from the sites in pyroclastic flows, however, were submitted to progressive thermal demagnetization to determine the ChRM direction and the settling temperature of the flow, i.e. whether or not the deposit was the result of a hot pyroclastic or cold debris flow. 
Table 1. Sampling sites. Lat. and Long. indicate latitude and longitude, respectively. The method of the numerical age is shown in parenthesis; K: $\mathrm{K}-\mathrm{Ar}, \mathrm{C}:{ }^{14} \mathrm{C}$, F: fission track, others are estimated geologically. The last column indicates the reference of the age. D93: Danhara et al. (1993), H99: Hoshizumi et al. (1999), H06: http://staff.aist.go.jp/h.hoshizumi/unzen/, M: Matsumoto et al. (in prep.), N88: Nakada et al. (1988), W93: Watanabe et al. (1993).

\begin{tabular}{|c|c|c|c|c|c|}
\hline Site No. & Flow Unit & Site Lat. $\left({ }^{\circ}\right)$ & Site Long. $\left({ }^{\circ}\right)$ & Age (ka) & Ref. \\
\hline \multicolumn{6}{|c|}{ Pyroclasitc flow sites } \\
\hline UZ01 & $90-95$ pcf. & 32.746 & 130.344 & 0 & \\
\hline UZ02 & 90-95 pcf. & 32.745 & 130.323 & 0 & \\
\hline UZ03 & Kureisibaru pcf. & 32.789 & 130.323 & $40 \pm 4(\mathrm{~K})$ & M \\
\hline UZ04 & Yuegawa pcf & 32.782 & 130.300 & $13.85 \pm 0.18(\mathrm{C})$ & H06 \\
\hline UZ10 & Newer Unzen pcf & 32.779 & 130.300 & $25.0 \pm 1.9(\mathrm{~K})$ & M \\
\hline UZ11 & Newer Unzen pcf & 32.779 & 130.300 & $25.0 \pm 1.9(\mathrm{~K})$ & M \\
\hline UZ12 & Newer Unzen pcf & 32.779 & 130.300 & $25.0 \pm 1.9(\mathrm{~K})$ & M \\
\hline UZ14 & Mutsugi pcf & 32.786 & 130.341 & $4.22 \pm 0.11(\mathrm{C})$ & H99 \\
\hline UZ15 & Kitakamikoba pcf & 32.751 & 130.344 & ca. 5 & \\
\hline UZ17 & Yugawachi pcf (lowest part) & 32.704 & 130.301 & $<80$ & H99 \\
\hline UZ18 & Yugawachi pcf (middle part) & 32.705 & 130.301 & $<80$ & H99 \\
\hline UZ22 & Older Unzen pcf & 32.772 & 130.327 & ca. 300 & \\
\hline UZ23 & Older Unzen pcf & 32.772 & 130.326 & ca. 300 & \\
\hline UZ24 & Older Unzen pcf & 32.773 & 130.327 & ca. 300 & \\
\hline UZ25 & Older Unzen pcf & 32.797 & 130.331 & ca. 300 & \\
\hline UZ30 & Nodake pcf & 32.729 & 130.296 & $73 \pm 4(\mathrm{~K})$ & H99 \\
\hline UZ33 & Furue pcf & 32.736 & 130.317 & $22 \pm 5(\mathrm{~K})$ & M \\
\hline UZ39 & Older Unzen pcf & 32.793 & 130.189 & ca. 300 & \\
\hline UZ43 & Older Unzen pcf & 32.830 & 130.223 & $309 \pm 8(\mathrm{~K})$ & M \\
\hline \multicolumn{6}{|c|}{ Lava sites } \\
\hline UZ05 & Shichimenyama lava & 32.770 & 130.346 & $5.1 \pm 1.4(\mathrm{~F})$ & D93 \\
\hline UZ06 & Tenguyama lava & 32.758 & 130.345 & ca. 5 & \\
\hline UZ07 & Kazaana lava & 32.761 & 130.297 & ca. 6 & \\
\hline UZ08 & Fugen top lava & 32.757 & 130.293 & ca. 6 & \\
\hline UZ09 & Tarukidaichi N. & 32.770 & 130.331 & $197 \pm 17(\mathrm{~K})$ & H99 \\
\hline UZ13 & Newer Unzen lava & 32.787 & 130.304 & $100 \pm 60(\mathrm{~K})$ & M \\
\hline UZ16 & Older Unzen lava & 32.810 & 130.344 & $308 \pm 10(\mathrm{~K})$ & M \\
\hline UZ19 & Tonosaka andesite & 32.689 & 130.274 & $500 \pm 200(\mathrm{~K})$ & N88 \\
\hline UZ20 & Older Unzen lava & 32.695 & 130.299 & ca. 300 & \\
\hline UZ21 & Lava from Mayuyama & 32.760 & 130.353 & ca. 5 & \\
\hline UZ26 & Older Unzen lava & 32.732 & 130.275 & $240 \pm 10(\mathrm{~K})$ & W93 \\
\hline UZ27 & Older Unzen lava & 32.720 & 130.285 & $432 \pm 14(\mathrm{~K})$ & M \\
\hline UZ28 & Tonosaka andesite & 32.727 & 130.278 & $500 \pm 200(\mathrm{~K})$ & N88 \\
\hline UZ29 & Older Unzen lava & 32.730 & 130.281 & $198 \pm 22(\mathrm{~K})$ & M \\
\hline UZ31 & Nodake lava & 32.739 & 130.303 & $73 \pm 4(K)$ & H99 \\
\hline UZ32 & Fukkoshi lava & 32.733 & 130.300 & $109 \pm 4(\mathrm{~K})$ & H99 \\
\hline UZ34 & Older Unzen lava & 32.804 & 130.336 & $230 \pm 20(\mathrm{~K})$ & M \\
\hline UZ35 & Torikabutoyama lava & 32.788 & 130.275 & $210 \pm 10(\mathrm{~K})$ & H99 \\
\hline UZ36 & Older Unzen lava & 32.751 & 130.210 & ca. 300 & \\
\hline UZ37 & Older Unzen lava & 32.750 & 130.210 & ca. 300 & \\
\hline UZ38 & Older Unzen lava & 32.767 & 130.197 & $260 \pm 20(\mathrm{~K})$ & W93 \\
\hline UZ40 & Older Unzen lava & 32.749 & 130.246 & ca. 300 & \\
\hline UZ41 & Older Unzen lava & 32.751 & 130.232 & ca. 300 & \\
\hline $\mathrm{UZ42}$ & Older Unzen lava & 32.806 & 130.212 & $384 \pm 40(\mathrm{~K})$ & M \\
\hline UZ44 & Nodake lava & 32.737 & 130.288 & $80 \pm 20(\mathrm{~K})$ & W93 \\
\hline $\mathrm{UZ45}$ & Nodake lava & 32.741 & 130.291 & $73 \pm 4(K)$ & H99 \\
\hline UZ46 & Myokendake lava & 32.758 & 130.290 & $25 \pm 10(\mathrm{~K})$ & H99 \\
\hline UZ47 & Fukkoshi lava & 32.751 & 130.281 & $112 \pm 26(\mathrm{~K})$ & H99 \\
\hline UZ48 & Fukkoshi lava & 32.751 & 130.281 & $112 \pm 26(\mathrm{~K})$ & H99 \\
\hline UZ49 & Older Unzen lava & 32.750 & 130.258 & ca. 300 & \\
\hline
\end{tabular}


Table 1 (continued).

\begin{tabular}{|c|c|c|c|c|c|}
\hline Site No. & Flow Unit & Site Lat. $\left({ }^{\circ}\right)$ & Site Long. $\left({ }^{\circ}\right)$ & Age (ka) & Ref. \\
\hline \multicolumn{6}{|c|}{ Lava sites (continued) } \\
\hline UZ50 & Older Unzen lava & 32.749 & 130.261 & $238 \pm 8(\mathrm{~K})$ & M \\
\hline $\mathrm{UZ51}$ & Older Unzen lava & 32.751 & 130.263 & $180 \pm 6(\mathrm{~K})$ & M \\
\hline $\mathrm{UZ52}$ & Older Unzen lava & 32.771 & 130.325 & $185 \pm 7(\mathrm{~K})$ & M \\
\hline UZ53 & Tarukidaichi NW & 32.774 & 130.322 & $187 \pm 53(\mathrm{~K})$ & H99 \\
\hline UZ54 & Older Unzen lava & 32.759 & 130.328 & $440 \pm 240(\mathrm{~K})$ & M \\
\hline UZ55 & Fukkoshi lava & 32.742 & 130.317 & $109 \pm 4(\mathrm{~K})$ & H99 \\
\hline UZ56 & Fukkoshi lava & 32.738 & 130.313 & $115 \pm 4(\mathrm{~K})$ & M \\
\hline UZ57 & Older Unzen lava & 32.723 & 130.309 & $177 \pm 10(\mathrm{~K})$ & M \\
\hline $\mathrm{UZ58}$ & Taruki-Higashi lava & 32.759 & 130.334 & $25 \pm 12(\mathrm{~K})$ & H99 \\
\hline UZ59 & Senbongi lava & 32.777 & 130.317 & $13 \pm 3(\mathrm{~F})$ & H99 \\
\hline UZ60 & Older Unzen lava & 32.756 & 130.266 & $197 \pm 7(\mathrm{~K})$ & M \\
\hline UZ61 & Older Unzen lava & 32.754 & 130.249 & ca. 300 & \\
\hline UZ62 & Older Unzen lava & 32.759 & 130.244 & $221 \pm 7(\mathrm{~K})$ & M \\
\hline UZ63 & Older Unzen lava & 32.783 & 130.215 & ca. 300 & \\
\hline UZ64 & Older Unzen lava & 32.780 & 130.237 & $327 \pm 11(\mathrm{~K})$ & M \\
\hline UZ65 & Suwaike basalt & 32.694 & 130.202 & $755 \pm 36(\mathrm{~K})$ & M \\
\hline UZ66 & Older Unzen lava & 32.709 & 130.223 & $303 \pm 10(\mathrm{~K})$ & M \\
\hline UZ67 & Older Unzen lava & 32.773 & 130.218 & $191 \pm 8(\mathrm{~K})$ & M \\
\hline UZ68 & Older Unzen lava & 32.703 & 130.280 & $449 \pm 14(\mathrm{~K})$ & M \\
\hline UZ69 & Tonosaka andesite & 32.692 & 130.279 & $500 \pm 200(\mathrm{~K})$ & N88 \\
\hline
\end{tabular}

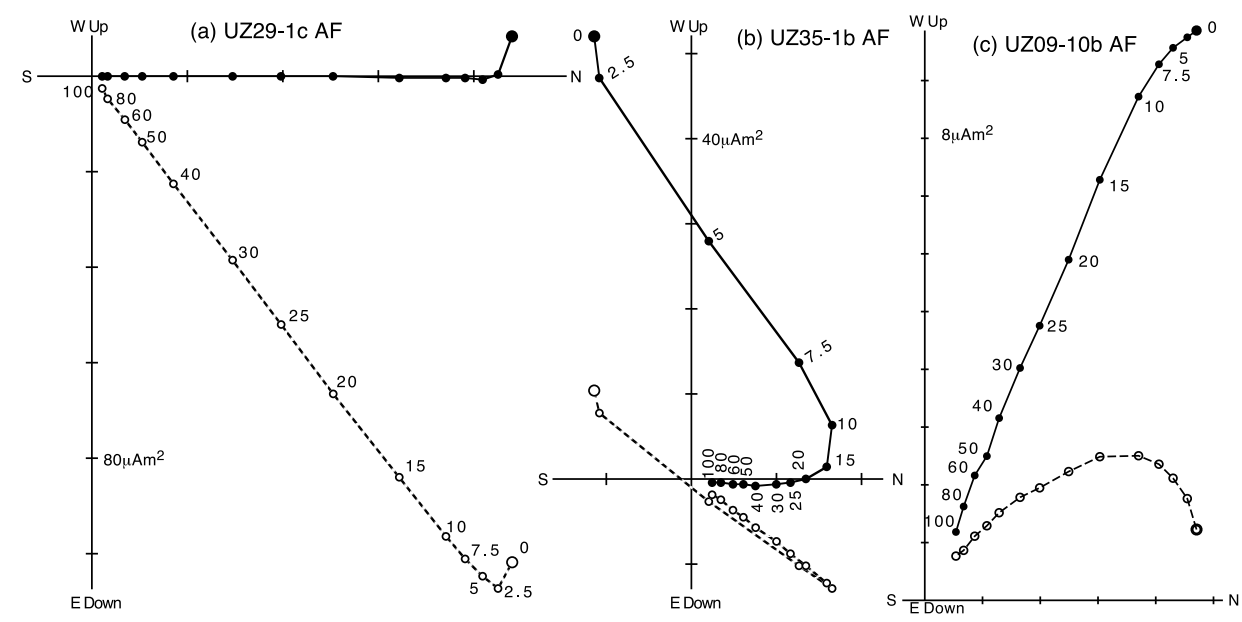

Fig. 2. Examples of progressive a.f. demagnetization, (a) of single component, (b) of double components and (c) from the excursion site.

\section{Results}

\subsection{Lava flows}

Remanent magnetizations of pilot specimens from the lava flows behaved well during progressive a.f. demagnetization. Demagnetization diagrams for specimens from most sites showed simple univectorial decay, and determining the a.f. step for blanket demagnetizations was straight forward (Fig. 2(a)). Samples from a few sites needed higher demagnetization levels, up to $40 \mathrm{mT}$, to isolate the primary magnetization, but the linear segment at high demagnetization levels was easily distinguished (Fig. 2(b) and (c)).

For individual specimens the difference between the blanket demagnetization direction and the direction calculated from linear fits to this point and those from higher demagnetization levels seldom exceeded 1 degree. Comparisons of mean directions for the blanket demagnetization and linear fitting methods were also made for 5 sites. Here the differences in mean directions were again less than $1^{\circ}$, and there was no systematic bias in the precision parameter $(k)$ values between the two methods.

Two sites, UZ59 and UZ61, had scattered directions of magnetization. These sites were in outcrops consisting of several blocks, and relative movements between the blocks could not be ascertained in the field. Thus, we sampled as many of the blocks as possible to determine which, if any, were detached from the others. Unfortunately, it turned out that all of the sampled blocks had moved, and we have eliminated the results for these sites from further discussion.

Within-site magnetic directions were generally well grouped, but at a few sites, outlying data points were observed. Most likely, these points can be attributed to some part of the sampling procedure like orientation error, and it 
Table 2. Paleomagnetic results. N: number of samples used/measured. Demag.: demagnetization method, AFD and ThD indicates that the direction of ChRM is calculated from the line fitting of alternating field or thermal progressive demagnetization, and numbers denote that the ChRM is represented by the vector after af demag. of the number in mT. Dec and Inc: Declination and Inclination of each site mean direction. $\alpha_{95}$ and $k$ : $95 \%$ confidence angle and precision parameters, VGP Lat and Long: Latitude and Longitude of the VGP. The marks at the left indicate that the sites have special notes in the text.

\begin{tabular}{|c|c|c|c|c|c|c|c|c|c|}
\hline \multirow[b]{2}{*}{ Site No. } & \multirow[b]{2}{*}{$\mathrm{N}$} & \multirow[b]{2}{*}{ Demag. } & \multirow[b]{2}{*}{ Dec. $\left({ }^{\circ}\right)$} & \multirow[b]{2}{*}{ Inc. $\left({ }^{\circ}\right)$} & \multirow[b]{2}{*}{$\alpha_{95}\left(^{\circ}\right)$} & \multicolumn{4}{|c|}{ VGP } \\
\hline & & & & & & $k$ & Lat. $\left({ }^{\circ} \mathrm{N}\right)$ & Long $\left({ }^{\circ} \mathrm{E}\right)$ & \\
\hline \multicolumn{10}{|c|}{ Pyroclastic flow sites } \\
\hline UZ01 & $8 / 8$ & ThD & -3.6 & 45.4 & 6.3 & 78.3 & 83.4 & -20.7 & $*$ \\
\hline UZ02 & $4 / 4$ & ThD & & & & 1.2 & & & \\
\hline UZ03 & $3 / 3$ & ThD & & & & 6.3 & & & \\
\hline UZ04 & $7 / 7$ & ThD-low & 6.6 & 44.2 & 9.2 & 43.8 & 81.1 & -91.4 & \\
\hline UZ10 & $6 / 6$ & ThD & & & & 1.9 & & & \\
\hline UZ11 & $8 / 8$ & ThD & -14.8 & 57.9 & 8.5 & 43.0 & 76.7 & 70.2 & \\
\hline $\mathrm{UZ12}$ & $6 / 6$ & ThD & & & & 1.5 & & & \\
\hline UZ14 & $7 / 7$ & ThD & 8.6 & 45.5 & 5.0 & 145.6 & 80.5 & -103.9 & $\dagger$ \\
\hline $\mathrm{UZ15}$ & $5 / 5$ & ThD & & & & 1.3 & & & \\
\hline UZ17 & $9 / 9$ & ThD & 59.0 & 63.5 & 3.9 & 171.9 & 43.5 & -173.1 & $*$ \\
\hline UZ18 & $8 / 8$ & ThD & 5.4 & 17.2 & 4.8 & 132.7 & 65.6 & -62.7 & $*$ \\
\hline UZ22 & $9 / 9$ & ThD & & & & 2.5 & & & \\
\hline $\mathrm{UZ23}$ & $5 / 5$ & ThD & & & & 1.6 & & & \\
\hline UZ24 & $6 / 6$ & ThD & -1.1 & 50.2 & 2.9 & 548.0 & 88.0 & -22.0 & \\
\hline UZ25 & $7 / 7$ & ThD & -1.4 & 46.7 & 11.1 & 30.4 & 85.0 & -35.3 & \\
\hline UZ30 & $9 / 9$ & ThD & & & & 1.1 & & & \\
\hline UZ33 & $6 / 11$ & ThD & -13.3 & 57.8 & 10.1 & 44.6 & 77.8 & 71.9 & \\
\hline UZ39 & $11 / 11$ & ThD & & & & 1.1 & & & \\
\hline UZ43 & $8 / 8$ & ThD-low & 1.0 & 37.4 & 7.2 & 71.7 & 78.1 & -54.3 & \\
\hline \multicolumn{10}{|l|}{ Lava sites } \\
\hline UZ05 & $8 / 8$ & AFD & 12.8 & 47.1 & 1.9 & 815.6 & 78.1 & -120.9 & $\dagger$ \\
\hline UZ06 & $7 / 7$ & AFD & -0.6 & 36.7 & 3.7 & 264.6 & 77.7 & -47.0 & \\
\hline UZ07 & $8 / 8$ & AFD & 18.1 & 57.4 & 5.5 & 103.0 & 74.4 & -164.4 & \\
\hline UZ08 & $6 / 6$ & AFD & 24.9 & 55.9 & 3.3 & 401.2 & 69.2 & -156.9 & \\
\hline UZ09 & $11 / 11$ & AFD & -72.6 & -21.0 & 2.6 & 305.4 & 8.3 & 21.6 & \\
\hline UZ13 & $7 / 7$ & AFD & 22.6 & 46.6 & 11.2 & 29.9 & 69.9 & -131.5 & \\
\hline UZ16 & $5 / 5$ & ThD & 24.0 & 49.2 & 5.6 & 189.1 & 69.4 & -138.5 & \\
\hline UZ19 & $7 / 8$ & 20 & 2.9 & 40.5 & 2.1 & 792.5 & 80.1 & -65.4 & \\
\hline UZ20 & $8 / 8$ & 25 & -33.9 & 50.7 & 2.4 & 521.9 & 61.4 & 47.0 & \\
\hline UZ21 & $7 / 8$ & 15 & -25.1 & 16.8 & 3.8 & 259.0 & 56.5 & -0.2 & \\
\hline UZ26 & $8 / 8$ & 20 & -29.8 & 44.8 & 2.3 & 585.7 & 63.4 & 34.4 & \\
\hline UZ27 & $8 / 8$ & 25 & -47.0 & 49.8 & 5.8 & 91.4 & 50.3 & 50.3 & \\
\hline UZ28 & $8 / 8$ & 20 & -6.5 & 66.3 & 2.3 & 591.3 & 73.3 & 115.2 & \\
\hline UZ29 & $9 / 9$ & 7.5 & -2.3 & 47.7 & 3.7 & 196.2 & 85.6 & -22.5 & \\
\hline UZ31 & $9 / 9$ & AFD & 22.9 & 46.0 & 8.8 & 35.3 & 69.5 & -130.5 & \\
\hline UZ32 & $8 / 8$ & 20 & -15.0 & 62.2 & 2.5 & 481.9 & 74.1 & 87.1 & $\dagger$ \\
\hline UZ34 & $8 / 9$ & 25 & -3.7 & 29.3 & 2.3 & 557.3 & 72.5 & -37.7 & \\
\hline UZ35 & $7 / 8$ & 40 & 8.0 & 39.5 & 2.9 & 429.3 & 77.4 & -86.0 & \\
\hline UZ36 & $9 / 9$ & 50 & 17.0 & 61.8 & 1.9 & 755.9 & 73.2 & 177.8 & \\
\hline UZ37 & $8 / 8$ & 10 & 18.6 & 59.6 & 1.9 & 814.7 & 73.3 & -172.4 & \\
\hline UZ38 & $8 / 8$ & 5 & 19.8 & 66.9 & 3.5 & 295.0 & 67.7 & 165.6 & \\
\hline UZ40 & $8 / 8$ & 15 & 11.6 & 53.9 & 2.6 & 452.8 & 80.2 & -152.8 & \\
\hline UZ41 & $6 / 6$ & 20 & 39.9 & 60.0 & 3.8 & 308.7 & 57.3 & -165.8 & \\
\hline UZ42 & $8 / 8$ & 20 & -6.7 & 48.4 & 4.9 & 129.4 & 83.3 & 11.2 & \\
\hline UZ44 & $11 / 11$ & 25 & 0.0 & 59.1 & 5.3 & 74.2 & 82.9 & 130.3 & \\
\hline $\mathrm{UZ45}$ & $7 / 7$ & 40 & -4.6 & 40.5 & 3.1 & 375.2 & 79.6 & -25.7 & \\
\hline UZ46 & $8 / 9$ & 40 & 2.1 & 47.2 & 1.2 & 2125.7 & 85.3 & -72.6 & \\
\hline UZ47 & $8 / 8$ & 25 & 11.2 & 55.3 & 2.9 & 377.3 & 80.3 & -161.2 & $\ddagger$ \\
\hline UZ48 & $6 / 6$ & 15 & 19.8 & 55.2 & 2.8 & 592.0 & 73.4 & -155.5 & $\ddagger$ \\
\hline UZ49 & $8 / 8$ & 15 & 2.6 & 46.6 & 2.3 & 606.1 & 84.6 & -75.1 & \\
\hline
\end{tabular}


Table 2 (continued).

\begin{tabular}{|c|c|c|c|c|c|c|c|c|c|}
\hline \multirow[b]{2}{*}{ Site No. } & \multirow[b]{2}{*}{$\mathrm{N}$} & \multirow[b]{2}{*}{ Demag. } & \multirow[b]{2}{*}{ Dec. $\left({ }^{\circ}\right)$} & \multirow[b]{2}{*}{ Inc. $\left({ }^{\circ}\right)$} & \multirow[b]{2}{*}{$\alpha_{95}\left(^{\circ}\right)$} & \multicolumn{4}{|c|}{ VGP } \\
\hline & & & & & & $k$ & Lat. $\left({ }^{\circ} \mathrm{N}\right)$ & Long $\left({ }^{\circ} \mathrm{E}\right)$ & \\
\hline \multicolumn{10}{|c|}{ Lava sites (continued) } \\
\hline UZ50 & $9 / 9$ & 15 & -0.1 & 48.9 & 2.6 & 389.2 & 87.1 & -48.0 & \\
\hline UZ51 & $9 / 9$ & 20 & -13.1 & 30.2 & 3.5 & 220.2 & 69.7 & -11.0 & \\
\hline UZ52 & $8 / 9$ & 15 & -7.7 & 46.4 & 3.2 & 293.3 & 81.6 & 5.0 & \\
\hline UZ53 & $8 / 9$ & 10 & -4.8 & 43.7 & 2.4 & 446.7 & 81.6 & -18.4 & \\
\hline UZ54 & $8 / 8$ & 50 & -1.1 & 31.0 & 3.9 & 201.5 & 73.9 & -45.9 & \\
\hline UZ55 & $8 / 8$ & 40 & -9.8 & 61.5 & 1.7 & 1115.3 & 77.4 & 95.2 & $\dagger$ \\
\hline UZ56 & $8 / 8$ & 20 & -0.5 & 70.4 & 3.1 & 319.6 & 68.2 & 129.5 & $\dagger$ \\
\hline UZ57 & $7 / 7$ & 40 & -5.5 & 33.2 & 2.0 & 870.8 & 74.6 & -29.7 & \\
\hline UZ58 & $6 / 8$ & 20 & -2.1 & 39.7 & 3.4 & 394.7 & 79.6 & -38.8 & \\
\hline UZ59 & $10 / 10$ & 40 & & & & 2.5 & & & \\
\hline UZ60 & $9 / 9$ & 40 & -0.6 & 46.7 & 3.5 & 217.2 & 85.2 & -43.4 & \\
\hline UZ61 & $9 / 9$ & 50 & & & & 3.6 & & & \\
\hline UZ62 & $8 / 8$ & 40 & 8.5 & 49.9 & 2.1 & 670.9 & 82.5 & -126.1 & \\
\hline UZ63 & $10 / 10$ & 7.5 & -3.2 & 50.9 & 1.1 & 1901.5 & 87.0 & 17.5 & \\
\hline UZ64 & $7 / 7$ & 10 & -6.4 & 54.4 & 2.3 & 713.0 & 84.3 & 64.0 & \\
\hline UZ65 & $8 / 8$ & 20 & 18.0 & 54.1 & 1.8 & 1000.8 & 74.9 & -152.1 & \\
\hline UZ66 & $8 / 8$ & 20 & -1.2 & 62.4 & 5.3 & 111.4 & 78.9 & 125.7 & \\
\hline UZ67 & $8 / 8$ & 40 & 17.9 & 56.4 & 1.8 & 976.7 & 74.8 & -160.7 & \\
\hline UZ68 & $8 / 8$ & 10 & 6.3 & 54.4 & 5.0 & 123.5 & 84.3 & -164.5 & \\
\hline UZ69 & $7 / 7$ & 25 & 0.0 & 43.5 & 2.5 & 599.0 & 82.7 & -49.7 & \\
\hline
\end{tabular}

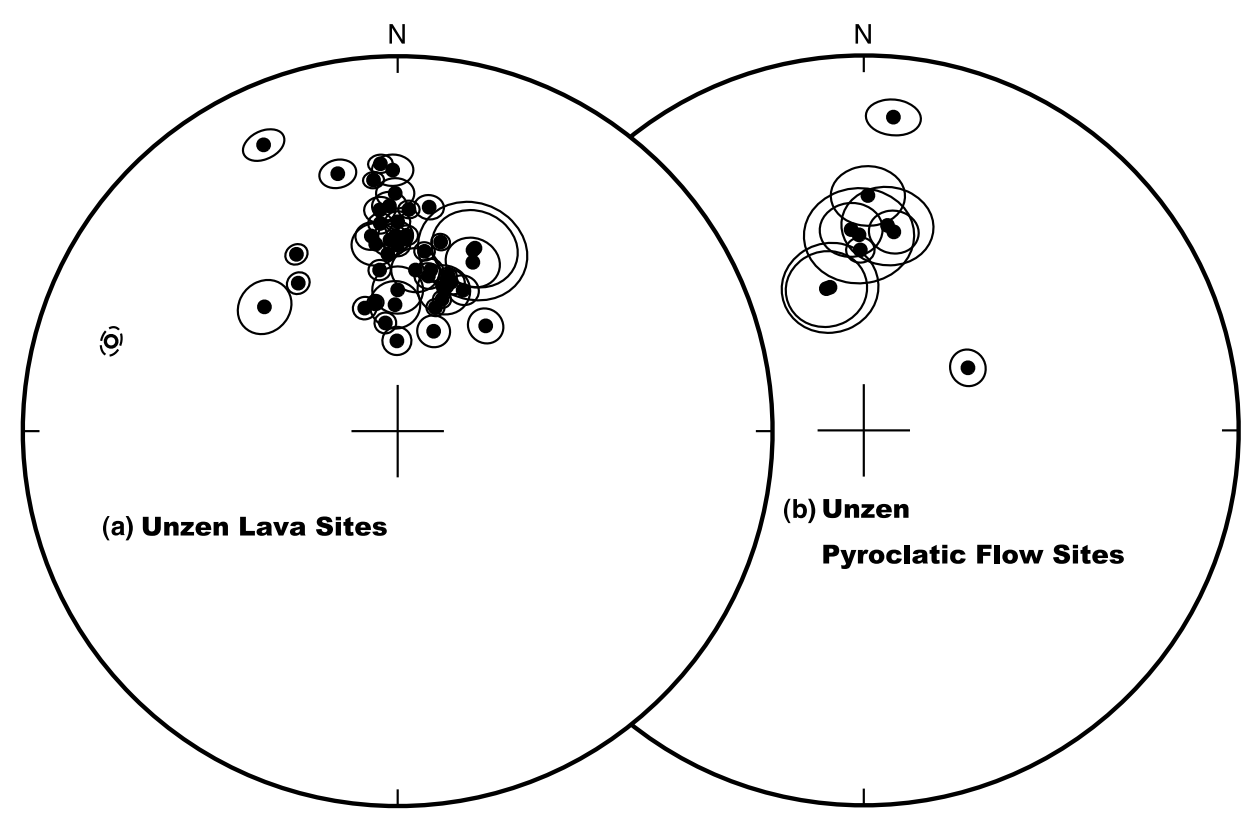

Fig. 3. Paleomagnetic site mean directions of (a) lava flow sites and (b) pyroclastic flow sites. All directions are on the lower hemisphere. Ellipses around symbols indicate the $95 \%$ confidence limits.

is very difficult to completely eliminate such errors. The criteria used to classify outliers were taken from McFadden (1982), and these data points were discarded before calculation of the site means. Data for eight sites contained such outliers, and, with the exception of one site, had only one outlier each.

The paleomagnetic statistics for each site are tabulated in Table 2, and the site-mean directions are illustrated in
Fig. 3(a). Out of 50 sites, we obtained 48 site means with $k>20$; concentrations of the magnetic directions were mostly good with precision parameters commonly exceeding 300 .

\subsection{Pyroclastics flows}

Pyroclastic flows (pcfs) were initially sampled because we expected them to have settled at high temperatures and to have retained stable in situ paleomagnetic directions. 
(a) UZ22-4b ThD

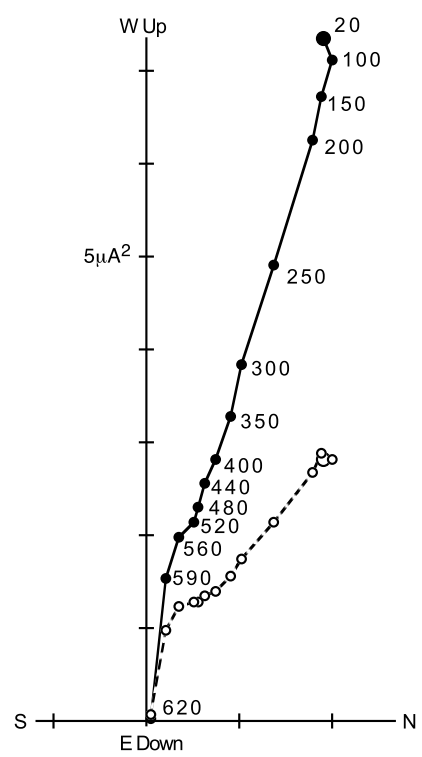

(b) UZ22 Low-T Component

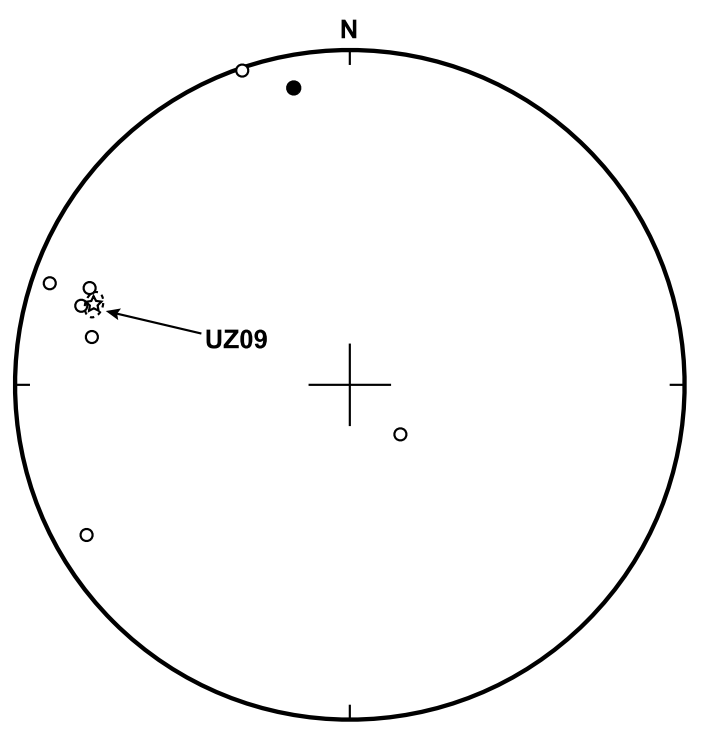

Fig. 4. (a) Orthogonal demagnetization diagram of a sample from site UZ22 in a pyroclastic flow, which is correlated with the UZ09 Senbongi excursion site, showing that it has two components. (b) The directions of a low-temperature component, along with the site mean direction of UZ09.

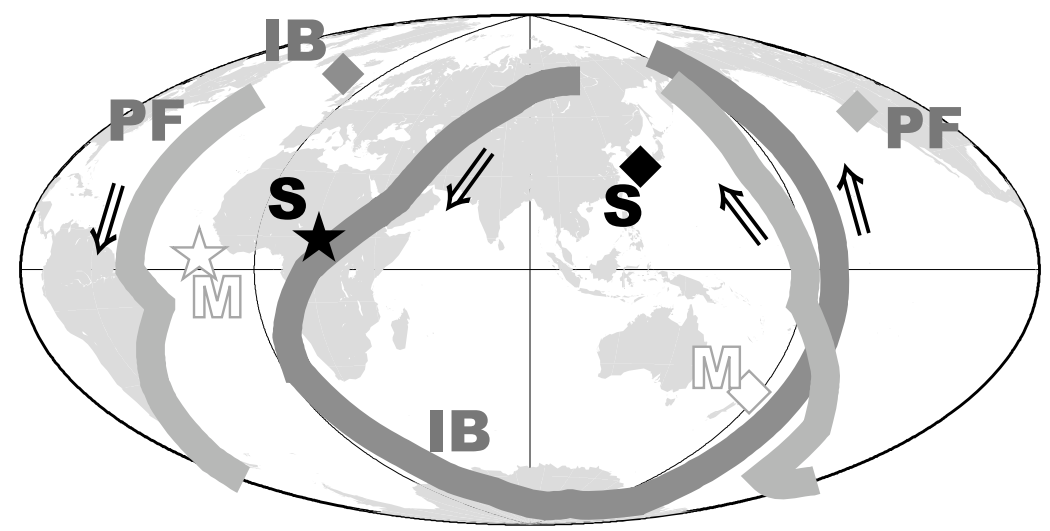

Fig. 5. VGP position of the Senbongi excursion (S), superimposed on the VGP position of the Mamaku excursion (M) and VGP-paths of the Iceland Basin (IB) and Pringle Falls (PF) excursions. Diamonds indicate the site locations.

Samples from all of the pcf sites therefore were subjected to progressive thermal demagnetization. We believed that even if the settlement temperature was less than the Curie temperature of the constituent magnetic minerals we should be able to isolate a ChRM. Data for many sites, however, showed scattered directions with $k<10$ for both high and low temperature ranges, indicating that the "pyroclastic flow' deposits were near the ambient temperature at the time of deposition. In this case the term 'volcanic breccias' is perhaps more appropriate for these rocks, although we will still refer to them using their field name of 'pyroclastic flows'; further discussion of this problem was presented by Tanaka et al. (2004). Details of the demagnetization characteristics for these rocks were also described in this earlier paper.

Within pcfs it is often difficult to distinguish blocks that were hot at the time of deposition from cold ones based on field observations alone, because the cold material mixed in could have been an earlier product of the same eruptive series. Apparently the pcf sampled at site UZ33 was de- posited with both hot and cold blocks; magnetic directions for 6 samples form a rather tight cluster while 5 other samples from the site have widely scattered directions. We were at first afraid that we might find many sites like UZ33, since the rejection criteria of directions would be subjective for such sites, but in all other cases the precision parameters were clearly divided between sites with clustered or scattered directions.

The means for only 10 sites had $k>20$, and the precision parameters generally indicated more scattered data than for the sites in lava flows. This is probably due to the movement of cobble blocks before or at the time of sampling. The statistics for site-mean directions for the pcfs are listed in Table 2 and are illustrated in Fig. 3(b).

\section{Discussion}

\subsection{Senbongi excursion}

As expected from the lava flow ages, all but one of the site-mean directions was of normal polarity, i.e., the corresponding VGP latitudes were greater than $50^{\circ} \mathrm{N}$. The ex- 


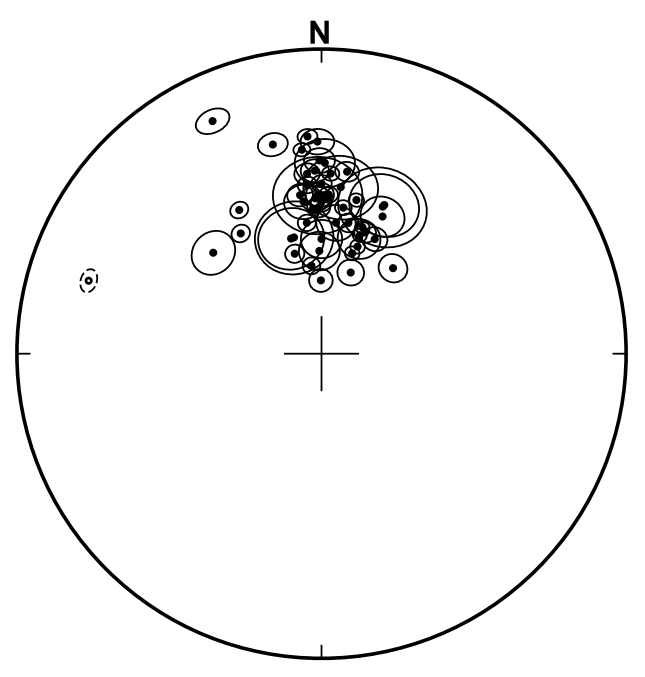

(a)

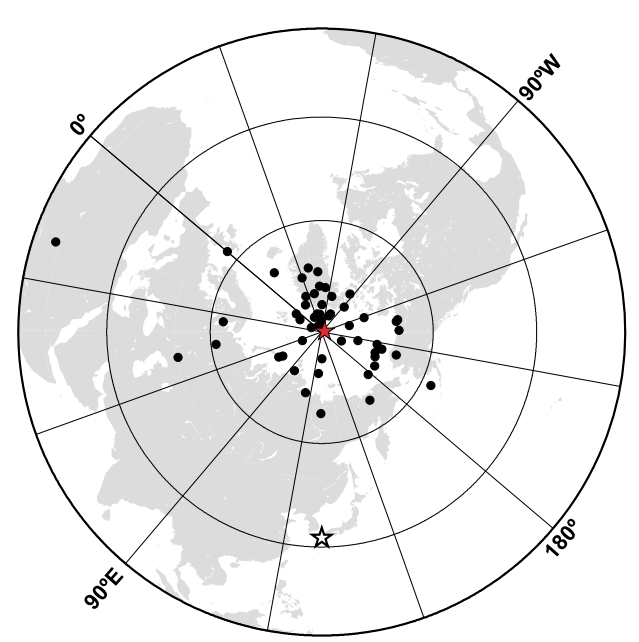

(b)

Fig. 6. Paleomagnetic direction (a) and VGP (b) plots of the Unzen sites. Duplicated sites are excluded as described in the text. Solid and open stars in (b) are the mean VGP excluding the excursion site, and the location of Unzen volcano, respectively.

ception was the direction for site UZ09 which has a VGP latitude as low as $8.3^{\circ} \mathrm{N}$. This intermediate direction/VGP appears to have recorded an excursion of the geomagnetic field, although we could not find another outcrop within the same lava flow to confirm that it is not due to a large block rotation of the sampling site. The site is on the edge of a gentle ridge that seems to have been formed by the lava flow itself, so there is no possibility of the sampled rocks having fallen off this higher part. Other evidence supporting the interpretation of an excursion is the paleomagnetic direction from site UZ22 in a pcf. This flow is stratigraphically close the UZ09 lava flow, and the two are thought to have been erupted at about the same time. Progressive thermal demagnetizations show that most of the samples from site UZ22 have two magnetic components. The directions of these components tend to be widely scattered, but there is a cluster of data points similar to the UZ09 mean direction (Fig. 4). These relationships could be explained if (1) the UZ09 lava flow and UZ22 pcf were emplaced during the same eruptive episode, (2) several blocks within the UZ22 flow were deposited at temperatures around $350^{\circ} \mathrm{C}$, and (3) the episode occurred at the time of a geomagnetic excursion. Hereafter we will call this excursion the Senbongi excursion.

The K-Ar age for the UZ09 lava flow is $197 \pm 17 \mathrm{ka}$ (Matsumoto et al., in prep.). Wollin et al. (1971), Ryan and Flood (1972), and Kawai et al. (1972) initially reported a geomagnetic excursion or short event at about $200 \mathrm{ka}$ from marine or lacustrine sediment cores. Champion et al. (1988) reviewed the geomagnetic events within the Brunhes chron and referred to the event at $200 \mathrm{ka}$ as the Jamaica/Biwa I event. Herrero-Bervera et al. (1994) produced a ${ }^{40} \mathrm{Ar} /{ }^{39} \mathrm{Ar}$ age of $218 \pm 10 \mathrm{ka}$ on a tuff layer proximal to a geomagnetic event they called the Pringle Falls event that has been found in a number of lake deposits in the western USA. Among other reports of a $\sim 200 \mathrm{ka}$ excursion is Channell et al.'s (1997) documentation of what they call the Iceland Basin event from detailed paleomagnetic and oxygen isotope logs of sediment APC cores retrieved off Iceland (ODP Site 983). Channell (1999) argues that the age of the Iceland Basin event (189-186 ka) is distinguishable from that of the Pringle Falls event, and that there might be two separate events, although they could not find clear evidence of the Pringle Falls event in the Iceland Basin cores. In addition, he argued that the Iceland Basin records and dates of the $\sim 200$ ka excursion are so much improved that it should be referred as the Iceland Basin (IB) event. As the relation between the IB and Pringle Falls (PF) excursions is not well established, we will refer to the excursion at $\sim 200 \mathrm{ka}$ together as the name of IB/PF event.

Assuming the existence of two events at $\sim 200 \mathrm{ka}$, it is not clear which event the Senbongi excursion correlates with. The age of the Iceland Basin event is closer than that of the Pringle Falls event to the age of the Senbongi excursion, although the Pringle Falls and Senbongi ages are similar within error limits. In either case, the Senbongi excursion appears to be well correlated with the IB/PF event.

The VGP for the Senbongi excursion is located at $8.3^{\circ} \mathrm{N}$, $21.6^{\circ} \mathrm{E}$ in central Africa, and is shown in Fig. 5 along with the schematic VGP paths for the IB (Channell, 1999) and PF events (Herrero-Bervera et al., 1994). Although the meaning of an intermediate VGP location during an excursion should be treated with caution, the Senbongi VGP falls almost exactly on the VGP path for the IB event and not on the PF VGP path perhaps supporting the correlation.

Laj et al. (2006) studied four sediment cores from the North Atlantic Basin and South China Sea, and discussed in detail the VGP paths calculated from all of the available paleomagnetic data reported for the IB event. In addition to their own data they identified three other reliable data sets from among the published records, including a record from Lake Baikal (Oda et al., 2002). The VGP paths for these data sets also pass through central Africa in agreement with the Senbongi VGP. Although the comparison of intermediate VGP locations over large distances might be invalid using the dipole hypothesis, the agreement between 
the sites in East Asia (Lake Baikal, South China Sea, Senbongi) would support the correlation of the observed excursions

It is interesting to note that another report of the IB/PF event from volcanic rocks seems to have similar coincidence, but to the PF event. The excursional magnetic direction of the Mamaku ignimbrite on the North Island of New Zealand was first reported by Cox (1969a). Shane et al. (1994) and Tanaka et al. (1996) confirmed the excursion, and dated it at $0.23 \pm 0.01$ Ma by fission track, and at $0.22 \pm 0.01 \mathrm{Ma}$ by ${ }^{40} \mathrm{Ar} /{ }^{39} \mathrm{Ar}$ methods, respectively. McWilliams (2001) compared the PF and Mamaku VGPs, and concluded that the two records were of a single event. Moreover, the Mamaku ignimbrite VGP comes close to the PF VGP path, although there is an offset of about $30^{\circ}$. This offset is within normal secular variation on the geomagnetic field, so the conclusion of McWilliams (2001) appears appropriate. Such coincidences may indicate that aborted reversals at IB/PF time flipped the dipole of dominant intensity.

4.2 Averaged paleomagnetic direction and the dispersion

Combining the site-mean data for both lava flows and pcfs, we obtained mean ChRM directions for 58 out of 69 sites with $k>20$. Although a cut-off threshold of $k=20$ might be considered too low, this threshold was not designed for calculating mean directions to represent paleosecular variation, but, as we will see later, for discussing the statistical character of the data set.

Samples at some sites were deliberately collected from the same geological unit to test its classification. Tanaka et al. (2004) discussed the details of these tests and concluded that (1) the pcf at site UZ14 (Mutsugi pcf) was erupted from the same volcanic episode as the lava flow at site UZ05 (Shichimenyama lava flow), (2) two sites in the north lobe of the Fukkoshi lava flow (UZ47 and UZ48) have barely distinguishable paleomagnetic directions, and (3) two sites (UZ32 and UZ55) in the south lobe of the Fukkoshi lava flow have similar directions although the direction for a third site (UZ56) is different. Since sites UZ14 and UZ05, and sites UZ32 and UZ55, have statistically indistinguishable mean directions, these directions should not be thought of as independent samples of the secular variation. We have simply chosen the site means with smaller $\alpha_{95}$ values from each pair (UZ05 and UZ32) to best represent the ambient field directions for these flows. Although sites UZ47 and UZ48 have similar mean directions, the directions are statistically distinguishable because of their small $\alpha_{95}$ values. Since the age of magnetization acquisition is most likely the same at both sites, we select the direction for site UZ48 (smaller $\alpha_{95}$ ) as the most representative. We also exclude the direction for the recent pcf at site UZ01 and substitute the present geomagnetic field direction $\left(D=-6.4^{\circ}\right.$, $I=47.1^{\circ}$ ) for Nagasaki City (National Astronomical Observatory Japan, 2004).

Sites UZ17 and UZ18 are in different parts of the same pcf. Their mean paleomagnetic directions, however, are quite different being $\sim 50^{\circ}$ apart from one another. Thus, we discard these two sites from any further discussion.

Another problematic result is for site UZ21 that is from the same geological unit as site UZ06 (Tanaka et al., 2004), but has a significantly different direction (Table 2; Fig. $3)$. Two explanations are possible for the lower inclination $\left(\sim 20^{\circ}\right)$ of the UZ21 mean direction: Either (1) slump movement of a large block including site UZ21 has occurred, or (2) two different lava flows were sampled. Site UZ06 was collected from the top of a lava dome, and UZ21 is located on its eastern flank. A $30^{\circ}$ tilt about a horizontal axis to the ESE is needed to move the UZ06 direction into coincidence with the UZ21 direction. Large-scale slump movements in the area, however, are to the east and would tilt the UZ06 block westward, thus moving the UZ06 direction to the east rather than to the UZ21 direction. Therefore, the UZ06 and UZ22 sites are most likely in different lava flows, and we treat the site means as two separate records of PSV.

The 53 individual site-mean directions and corresponding VGPs are plotted in Fig. 6(a) and (b), respectively. In order to eliminate unreliable data, we have initially set an upper limit for $\alpha_{95}$ values at $10^{\circ}$, and will later look at the effects of changing this limit. Excluding means with $\alpha_{95}>10^{\circ}$ and the excursion direction (UZ09), the remaining 49 site means give an overall mean direction of $D_{\mathrm{m}}=0.4^{\circ}, I_{\mathrm{m}}=49.8^{\circ}$ with $\alpha_{95}=3.7^{\circ}$ and $k=31.3$. This observed direction agrees well with the expected direction calculated from a geocentric axial dipole field with an expected inclination of $52.1^{\circ}$. The mean for the 49 VGPs is at $88.7^{\circ} \mathrm{N}, 87.5^{\circ} \mathrm{W}\left(A_{95}=4.1^{\circ}, k=25.3\right)$ and is statistically indistinguishable from the geographic pole. No far-sided or near-sided effects of the VGP dataset are observed. The angular standard deviation (ASD) for the mean pole is $16.3^{\circ}$ $\left(-2.6^{\circ} /+2.8^{\circ}\right)$, with the error calculated after the method of Cox (1969b). ASD values for Japan will be discussed in greater detail in the next section after compiling other relevant data available in the scientific literature.

\subsection{Brunhes PSV in Japan}

Studies of the stochastic paleosecular variation for Japan were few in the early years of Japanese paleomagnetism, in spite of the fact that Japanese paleomagnetists made significant contributions to a number of related fields. The first paleomagnetic investigations to estimate the ASD for Brunhes-aged rocks in Japan were made by Heki (1983) with data for 29 lava flows in the Higashi Izu and Kagoshima regions that are separated by about $800 \mathrm{~km}$. Since then, five more papers reporting Bruhnes paleomagnetic directions from volcanic rocks have been published (Tsunakawa and Hamano, 1988; Ishikawa and Tagami, 1991; Otake et al., 1993; Morinaga et al., 2000; Tanaka and Kobayashi, 2003). This makes available a total of 122 Brunhes-aged VGPs with $\alpha_{95}<20^{\circ}$ to which we add 51 VGPs for a combined total of 173 VGPs; we will refer to this combined total as the JB06 dataset.

In calculating a mean pole and ASD, it is common practice to set two limits on the input data, the first being a maximum threshold for the site-mean $\alpha_{95}$ values and the second being a maximum threshold for colatitude $\left(\theta_{c}\right)$ above which the VGP is assumed to be part of a field polarity excursion or transition rather than normal PSV. To examine the effect of changing the $\alpha_{95}$ maximum cut-off value we graphed it vs. ASD in Fig. 7(a). Although ASDs decrease with maximum $\alpha_{95}$ values less than $\sim 6^{\circ}$, this appears to be a statistical 


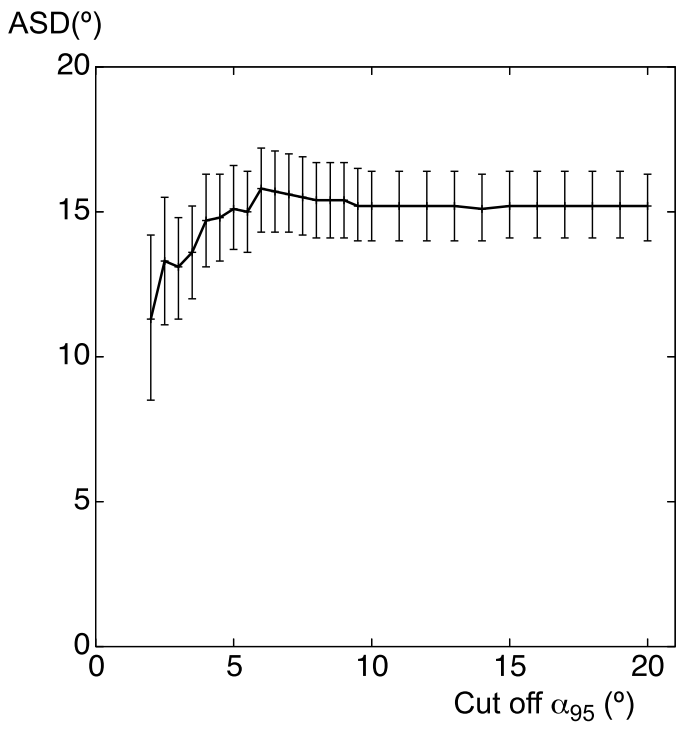

(a)

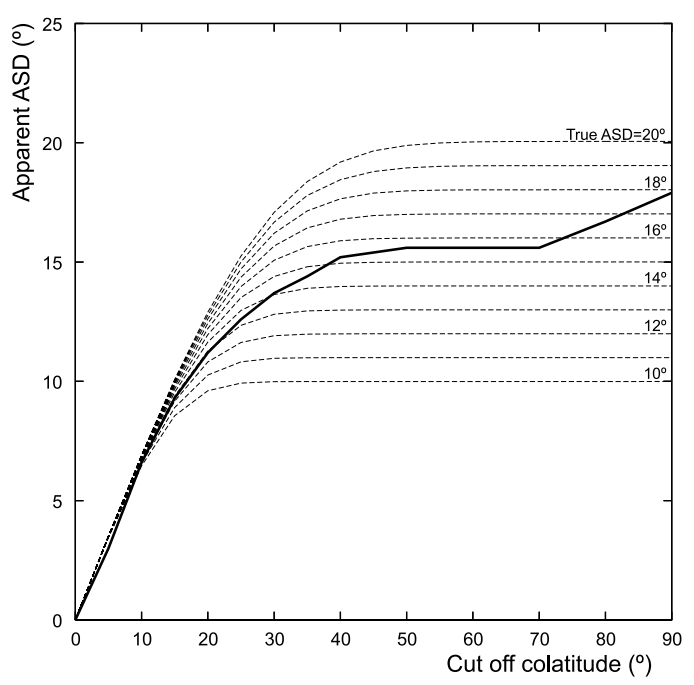

(b)

Fig. 7. ASD variation of JB06-a10 dataset with changing cutoff (a) $\alpha_{95}$ and (b) $\theta_{\mathrm{c}}$. Dotted lines in (b) indicate the change of apparent ASD for Fisher distributions with true ASD values denoted by the lines.

artifact as the ASD for an $\alpha_{95}$ cut-off value of $10^{\circ}$ is statistically similar to all of the other ASDs. Thus, we have set the $\alpha_{95}$ cut-off value to the commonly used $10^{\circ}$ which reduces the number of VGPs in the dataset to 150 ; we will call this dataset the JB06-a10 dataset.

The greatest problem in calculating an accurate ASD is determining the correct $\theta_{c}$ value. The calculated ASD is proportional to the arbitrarily chosen $\theta_{\mathrm{c}}$ value, but if we use all VGPs the ASD strongly depends on the presence of a few intermediate VGPs. Setting $\theta_{\mathrm{c}}$ to $50^{\circ}$ as is commonly done, the ASD for the JB06-a10 dataset is $15.2^{\circ} \pm 1.2^{\circ}$ $(N=148)$. It should be noted that there are 3 VGPs $(2 \%)$ having latitudes between $50^{\circ}$ and $55^{\circ}$, while only $0.5 \%$ is

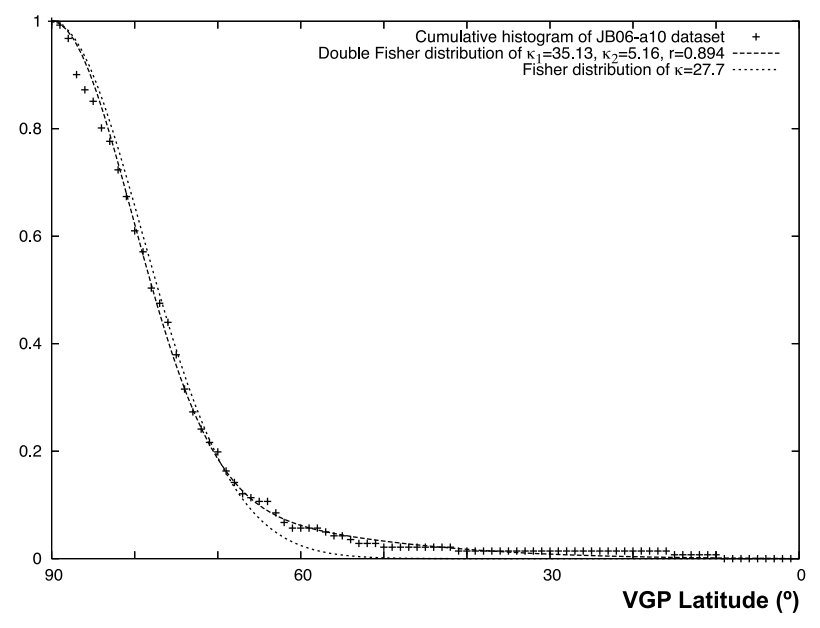

Fig. 8. Cumulative histogram of the JB06-a10 dataset and optimum single and double Fisher distributions.

expected for the corresponding Fisherian distribution, and this tendency is often seen in other PSVL studies as well (Shibuya et al., 1995). The calculated ASD with $\theta_{\mathrm{c}}=50^{\circ}$ apparently meets the standard models of PSV (e.g. McElhinny and McFadden, 1997), but we will now consider the meaning of the ASD in greater detail.

Figure 7(b) illustrates the apparent change in ASD versus $\theta_{\mathrm{c}}$ for the JB06-a10 dataset (solid curve). Also shown are values for modeled Fisherian distributions with true ASDs ranging between $10^{\circ}$ and $20^{\circ}$ (dashed curve). Assuming the observed distribution is Fisherian, it is expected that the solid curve would follow on one of the dotted curves. As this is not the case for the JB06-a10 dataset (the solid line crosses dotted lines of $\mathrm{ASD}=15^{\circ}$ to $13^{\circ}$ as $\theta_{\mathrm{c}}$ decreases from $50^{\circ}$ to $20^{\circ}$ ), the observed distribution is not Fisherian even after omitting the outliers.

Several methods have been proposed to avoid the problem of arbitrarily assigning $\theta_{\mathrm{c}}$ to a given dataset. Vandamme (1994) developed an algorithm to determine $\theta_{c}$ in which the VGPs farthest from the current mean are removed until the dataset fulfills a certain criterion. The problem with this algorithm, however, is that the reverse calculation, starting with a few VGPs at high latitudes and adding on until the dataset fails the criterion, often gives a different $\theta_{\mathrm{c}}$ value. In practical terms, the algorithm is not robust enough to handle the small changes caused by a few critical VGPs. Another problem with this algorithm is that Vandamme assumes that the input dataset follows a Fisherian distribution plus a uniform distribution. The nature of the observed distribution itself, however, is an open question in PSV studies.

Shibuya et al. (1995) proposed characterizing PSV by fitting a double Fisherian distribution (sum of two Fisherian distributions) to the cumulative histogram of the given dataset. They assumed that geomagnetism has two periods of different stability, normal and excursional, and that VGPs of each period have Fisherian distributions with different $\kappa$. Applying this method to the JB06-a10 dataset gives the precision parameters of the two Fisherian distributions as $\kappa_{1}=35.13$ and $\kappa_{2}=5.16$, and the ratio of 0.894:0.106 (Fig. 8). The $\kappa_{1}$ value corresponds to an ASD value of $13.7^{\circ}$, and it is interesting to note that this value is as low 
as those for other areas in the Pacific region (Shibuya et al., 1995). This ASD value for Japan is lower than the one given by Shibuya et al. (1995), partly because the new dataset is larger and restricted to the Brunhes chron, but moreover because they used a single Fisherian distribution as there were few intermediate VGPs in the dataset available at that time. Parametric bootstrap simulations of the distribution indicate that the calculated ASD is not stable, particularly when intermediate VGPs are scarce. It is also understood that a greater number of parameters to determine introduces greater error in each of the parameters.

In setting a fixed $\theta_{c}$ value for datasets from around the world, the calculated ASDs are still a relatively robust measure of the scattering. The strict meaning of these ASDs, however, remains unclear. Perhaps we need to find a more appropriate distribution for PSVL than that proposed by Fisher, as well as a corresponding statistical parameter representing the dispersion.

\section{Summary}

(1) Fifty reliable paleomagnetic directions were obtained for lava and pyroclastic flows from Unzen Volcano. Ages for many of these flows have been determined using the K-Ar method, and the undated flows have been stratigraphically related to the dated flows by field observations. All flows were deposited within the Brunhes chron.

(2) An excursion, named the Senbongi excursion, was identified from an intermediate VGP for the Senfongi lava flow dated at $197 \pm 17 \mathrm{ka}$. The resolution of the age for the Senbongi excursion is not high enough to correlate it with either the Iceland Basin or Pringle Falls event. The coincidence of the Senbongi VGP with the Iceland Basin record likely supports their correlation.

(3) The Unzen dataset increases the Brunhes PSVL dataset for Japan by a factor of 1.5 times. The ASD calculated using the conventional cutoff for VGPs at $50^{\circ}$ latitude is $15.2^{\circ} \pm 1.2^{\circ}(N=148)$. The distribution of data points is better fitted by a double Fisherian distribution which gives an ASD of $13.7^{\circ}$. The distribution, however, appears to depart from a Fisherian distribution, and this may be the reason why the ASDs calculated from the two different methods are discordant

Acknowledgments. This study was carried out as one of the surface studies of the Unzen Scientific Drilling Project (USDP) which was financially supported by the Ministry of Education, Culture, Sports, Science, and Technology (MEXT). We thank Kozo Uto of the Geological Survey of Japan not only for his constant encouragement given to us as a project leader but also for much help with the fieldwork. We also thank Yuji Yamamoto of University of Liverpool for invaluable discussion and comments. The reviews' (Toshitsugu Yamazaki and Jon Hagstrum) comments and suggestions greatly improved the manuscript.

\section{References}

Champion, D. E., M. A. Lanphere, and M. A. Kuntz, Evidence for a new geomagnetic reversals in the Brunhes and Late Matuyama polarity chrons, J. Geophys. Res., 93, 11667-11680, 1988.

Channell, J. E. T., Geomagnetic paleointensity and directional secular variation at Ocean Drilling Program (ODP) Site 984 (Bjorn Drift) since 500 ka: Comparisons with ODP Site 983 (Gardar Drift), J. Geophys. Res., 104, 22937-11951, 1999.

Channell, J. E. T., D. A. Hodell, and B. Lehman, Relative geomagnetic paleointensity and $\delta^{18} \mathrm{O}$ at ODP Site 983 (Gardar Drift, North Atlantic) since 350 ka, Earth Planet. Sci. Lett., 153, 103-118, 1997.

Cox, A., A paleomagnetic study of secular variation in New Zealand, Earth Planet. Sci. Lett., 6, 257-267, 1969a.

Cox, A., Confidence limits for the precision parameter $\kappa$, Geophys. J. R. astr. Soc., 18, 545-549, 1969b.

Danhara, T., H. Iwano, H. Hoshizumi, and K. Watanabe, Fission track dating of very young zircon from the Unzen volcano, Prog. Abstr., Volcanol. Soc. Jpn., 2, 51, 1993 (in Japanese).

Heki, K., Paleomagnetic study of the Higashi-Izu monogenetic volcano group and pyroclastic flow deposits in Kagoshima Prefecture: Paleosecular variation during the last 40,000 years in Japan, J. Geomag. Geoelectr., 35, 383-390, 1983.

Herrero-Bervera, E., C. E. Helsley, A. M. Sarna-Wojcicki, K. R. Lajoie, C. E. Meyer, M. O. McWilliams, R. M. Negrini, B. D. Turrin, J. M. Donnelly-Nolan, and J. C. Liddicoat, Age and correlation of a paleomagnetic episode in the western United States by ${ }^{40} \mathrm{Ar} /{ }^{39} \mathrm{Ar}$ dating and tephrochronology: The Jamaica, Blake, or a new polarity episode?, J. Geophys. Res., 10, 24091-24103, 1994.

Hoshizumi, H., K. Uto, and K. Watanabe, Geology and eruptive history of Unzen volcano, Shimabara Peninsula, Kyushu, SW Japan, J. Volcanol. Geotherm. Res., 89, 81-94, 1999.

Hoshizumi, H., K. Uto, and A. Matsumoto, Geology and petrology of Unzen volcano, Field Guidebook, A3: Unzen and Aso Volcanoes, XXIII General Assembly of the International Union of Geodesy and Geophysics, p. 11-19, 2003.

Ishikawa, N. and T. Tagami, Paleomagnetism and fission-track geochronology on the Goto and Tsushima Islands in the Tsushima strait area: Implications for the opening mode of the Japan Sea, J. Geomag. Geoelectr., 43, 229-253, 1991.

Kawai, N., K. Yaskawa, T. Nakajima, M. Torii, and S. Horie, Oscillating geomagnetic field with a recurring reversal discovered from Lake Biwa, Proc. Jpn. Acad., 48, 186-190, 1972.

Laj, C., C. Kissel, and A. P. Roberts, Geomagnetic field behavior during the Iceland Basin and Laschamp geomagnetic excursions: A simple transitional field geometry?, Geochem. Geophys. Geosyst., 7, Q03004, doi:10.1029/2005GC001122, 2006.

McElhinny, M. W. and P. L. McFadden, Palaeosecular variation over the past 5 Myr based on a new generalized database, Geophys. J. Int., 131, 240-252, 1997.

McFadden, P. L., Rejection of palaeomagnetic observations, Earth Planet. Sci. Lett., 6, 392-395, 1982.

McWilliams, M., Global correlation of the 223 ka Pringle Falls Event, Int. Geol. Rev., 43, 191-195, 2001.

Morinaga, H., T. Matsumoto, Y. Okimura, and T. Matsuda, Paleomagnetism of Pliocene to Pleistocene lava flows in the northern part of Hyogo prefecture, Southwest Japan and Brunhes Chron paleosecular variation in Japan, Earth Planets Space, 52, 437-443, 2000.

Nakada, S. and H. Kamata, Petrogenetical relationship of basalts and andesites in southern part of the Shimabara Peninsula, Kyushu, Japan, J. Volcanol. Soc. Jpn., 33, 273-289, 1988 (in Japanese with English abstract).

Nakada, S., H. Shimizu, and K. Ohta, Overview of the 1990-1995 eruption at Unzen Volcano, J. Volcanol. Geotherm. Res., 89, 1-22, 1999.

National Astronomical Observatory Japan, Rika Nenpyo (Chronological Scientific Tables) 2005, Maruzen, Tokyo, 2004.

Oda, H., K. Nakamura, T. Ikehara, M. Nishimura, and O. Khlystov, Paleomagnetic record from Academician Ridge, Lake Baikal: A reversal excursion at the base of marine oxygen isotope stage 6, Earth Planet. Sci. Lett., 202, 117-132, 2002.

Otake, H., H. Tanaka, M. Kono, and K. Saito, Paleomagnetic study of Pleistocene lavas and dikes of the Zao Volcano Group, J. Geomag. Geoelectr., 45, 595-612, 1993.

Roberts, N. and J. D. A. Piper, A description of the behaviour of the Earth's magnetic field, in Geomagnetism, Vol. 3, edited by J. A. Jacobs, pp. 163-260, Academic Press, London, 1989.

Ryan, W. B. F. and J. D. Flood, Preliminary paleomagnetic measurements on sediments from the Ionian (Site 125) and Tyrrhenian (Site 132) basins of the Mediterranean Sea, Initial Rep. Deep Sea Drill. Proj., 13, 599-603, 1972.

Shane, P., T. Black, and J. Westgate, Isothermal plateau fission-track age 
for a paleomagnetic excursion in the Mamaku Ignimbrite, New Zealand, and implication for late Quaternary stratigraphy, Geophys. Res. Lett., 21, 1695-1698, 1994.

Shibuya, H., J. Cassidy, I. E. M. Smith, and T. Itaya, A geomagnetic excursion in Brunhes epoch recoreded in New Zealand basalts, Earth Planet. Sci. Lett., 111, 41-48, 1992.

Shibuya, H., J. Cassidy, I. E. M. Smith, and T. Itaya, Paleomagnetism of young New Zealand basalts and longitudinal distribution of paleosecular variation, J. Geomag. Geoelectr., 47, 1011-1022, 1995.

Tanaka, H. and T. Kobayashi, Paleomagnetism of the late Quaternary Ontake Volcano, Japan: directions, intensities, and excursions, Earth Planets Space, 55, 189-202, 2003.

Tanaka, H., G. M. Turner, B. F. Houghton, T. Tachibana, M. Kono, and M. O. McWilliams, Palaeomegnetism and chronology of the central Taupo Volcanic Zone, New Zealand, Geophys. J. Int., 124, 919-934, 1996.

Tanaka, H., H. Hoshizumi, Y. Iwasaki, and H. Shibuya, Applications of paleomagnetism in the volcanic field: A case study of the Unzen Volcano, Japan, Earth Planets Space, 56, 635-647, 2004.
Tsunakawa, H. and Y. Hamano, Paleomagnetic study of the Ashitaka dike swarm in Central Japan, J. Geomag. Geoelectr., 40, 221-226, 1988.

Tsunakawa, H., K. Heki, and K. Amano, Paleomagnetism of the Shimokura dike swarm in Northeast Japan, J. Geomag. Geoelectr., 37, 979-985, 1985.

Vandamme, D., A new method to determine paleosecular variation, Phys. Earth Planet. Inter., 85, 131-142, 1994.

Watanabe, K., H. Hoshizumi, and T. Itaya, K-Ar ages of Unzen volcano in Kyushu, Japan - with some aspects of geology of Mayu-yama, Mem. Fac. Educ. Kumamoto Univ., 42, 35-41, 1993.

Wollin, G., D. B. Ericson, W. B. F. Ryan, and J. H. Foster, Magnetism of the Earth and climate changes, Earth Planet. Sci. Lett., 12, 175-183, 1971.

H. Shibuya (e-mail: shibuya@sci.kumamoto-u.ac.jp), Y. Iwasaki, H. Tanaka, and H. Hoshizumi 